\title{
Evaluasi Kinerja Bangunan Rumah sakit Santa Maria Pemalang dengan Non-linier Static Pushover Analysis Metode ATC-40 dan FEMA 440
}

Bima Priya Hutama ${ }^{a^{*}}$

${ }^{a}$ Jurusan Teknik Sipil, Fakultas Sains dan Teknologi, Universitas Teknologi Yogyakarta, Indonesia

Keywords:

Non-linear

Performance Level

Pushover

Plastic Joint
Kata kunci:

Non-linier

Performance Level

Pushover

Sendi Plastis

\section{ABSTRACT}

The study of this final assignment was conducted by evaluating the earthquakeresistant performance of Santa Maria Hospital Structure in Pemalang to figure out the building's performance level based on the methods of ATC-40 and FEMA 440, as well as to find out the mechanism of formed plastic joints on the beam-column and to predict the collapse behavior. The research method used a response spectrum using a SAP2000v19 program. Based on ATC-40, performance point values for $x$-direction and $y$-direction were 0.00433 and 0.00408 . Those results show that the reviewed building structure categorized in the performance level of Immediate Occupancy (IO). Meanwhile, the analysis of structure damage level using FEMA 440 has resulted values for structure's lateral displacement target of $x$-direction was $0.17819 \mathrm{~m}$ and $y$ direction of $0.13524 \mathrm{~m}$, and categorized in the performance level of Immediate Occupancy (IO). Most of the plastic joint level on the beam and column has been categorized in the Immediate Occupancy (IO). In this category, it can be said that the performance of structure components are still in secured condition when displacement target achieved.

\section{ABSTRAK}

Penelitian ini dilakukan dengan mengevaluasi kinerja tahanan gempa Gedung Rumah Sakit Santa Maria Pemalang untuk mengetahui level kinerja bangunan (performance level) berdasarkan metode ATC-40 dan FEMA 440. Serta mekanisme terbentuk sendi plastis pada balok kolom dan memprediksi perilaku keruntuhan. Metode penelitian menggunakan respons spektrum dengan program SAP2000v19. Berdasarkan ATC-40 diperoleh nilai performance point untuk arah $\mathrm{x}=0,00433$ dan arah $\mathrm{y}=0,00408$. Hasil tersebut menunjukkan bahwa struktur gedung yang ditinjau termasuk dalam tingkat kinerja Immediate Occupancy (IO). Sedangkan hasil analisis tingkat kerusakan struktur menggunakan FEMA 440 menghasilkan nilai target perpindahan lateral struktur arah $\mathrm{x}=0,17819 \mathrm{~m}$, dan arah $\mathrm{y}=0,13524 \mathrm{~m}$ dan termasuk dalam kategori tingkat kinerja struktur Immediate Occupancy (IO). Sebagian besar tingkat sendi plastis balok dan kolom masih dalam Immediate Occupancy (IO). Dalam kategori ini dapat dikatakan kinerja komponen struktur masih dalam keadaan aman saat target perpindahan tercapai.

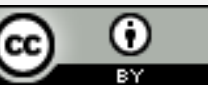

This is an open access article under the CC-BY license. 


\section{Pendahuluan}

Kondisi geologis Indonesia mempunyai potensi gempa yang relatif besar dengan melingkupi sebagian besar wilayahnya terutama di wilayah pulau Jawa, karena terletak pada jalur gempa Asia dan dan jalur gempa Pasifik. Gempa Bumi di Indonesia relatif sering terjadi, terutama akibat adanya interaksi pada lempeng tektonik karena Indonesia merupakan negara yang terletak pada empat lempeng tektonik dunia, yaitu lempeng Pasifik, lempeng Australia, Lempeng Eurasia, dan lempeng Filipina. Beberapa kejadian gempa di masa lalu juga telah banyak menimbulkan kerusakan dan banyak menelan korban jiwa.

Saat ini arah metode terbaru perencanaan tahan gempa beralih dari pendekatan kekuatan (force based) menuju pendekatan kinerja (performance based) dimana struktur yang direncanakan di analisis terhadap beberapa tingkat kinerja [1], [2]. Untuk mengetahui kinerja struktur saat menerima beban gempa, maka dibutuhkan analisis nonlinier yang sederhana tetapi cukup akurat. Salah satu cara analisis nonlinear yang dapat digunakan adalah Capacity Spectrum Method yang memanfaatkan analisis beban dorong statis nonlinier (nonlinear static pushover analysis) dengan menggunakan kinerja struktur sebagai target perencanaan yang pada intinya adalah mencari kapasitas struktur. Perencanaan berbasis kinerja mensyaratkan taraf kinerja (level of performance) yang diinginkan untuk suatu taraf beban gempa dengan periode ulang tertentu dengan menetapkan tiga tingkatan kinerja, yaitu kinerja batas layan (serviceablity limit state), kinerja kontrol kerusakan struktur (damage control limit state) dan kinerja keselamatan (safety limit state).

Nonlinear Static Pushover Analysis cukup akurat guna memprediksi pola keruntuhan suatu bangunan akibat adanya gempa. selain itu dengan mengevaluasi gedung rumah sakit Santa Maria Pemalang menggunakan Nonlinear Static Pushover Analysis memungkinkan bisa mencegah terjadinya kecelakan ataupun meprediksi pola keruntuhan suatu gedung akibat adanya gempa.

Sangat menarik untuk dilakukan evaluasi terhadap bangunan gedung rumah sakit Santa Maria Pemalang untuk memprediksikan perilaku kerusakan bangunan akibat gempa berdasarkan data dan kerusakan yang ada. Rumah sakit Santa Maria Pemalang berdiri di atas tanah seluas $16.144 \mathrm{~m}^{2}$ dengan luas bangunan $1.273 \mathrm{~m}^{2}$, terdiri dari 5 lantai dan dilengkapi dengan fasilitas lift. Lantai 1 berfungsi sebagai tempat untuk ruang Emergency, Radiologi, dan rekam medik. Sedangkan lantai 2 berfungsi sebagai klinik, Lantai 3 berfungsi sebagai Rawat inap, Lantai 4 berfungsi sebagai ruang operasi dan lantai 5 sebagai ruang AHU. Kondisi tersebut dapat dilihat langsung ke lokasi rumah sakit Santa Maria Pemalang ataupun dapat di lihat dari gambar DED. Karakteristik dari pembangunan gedung rumah sakit Santa Maria Pemalang itu sendiri dirancang dengan nuansa urban modern dan penuh gaya. Dengan dilakukannya evaluasi pada bangunan rumah sakit Santa Maria Pemalang untuk mengetahui kinerja struktur dengan mengunakan pushover di harap dapat mengetahui perilaku-perilaku yang terjadi pada kinerja struktur bangunan terhadap gaya geser maksimum dan deformasi yang terjadi [3].

\section{Metode}

Kinerja struktur merupakan tingkatan performa suatu struktur terhadap gempa rencana. Tingkatan performa struktur dapat diketahui dengan melihat tingkat kerusakan pada struktur saat terkena gempa rencana dengan periode ulang tertentu, oleh karen itu tingkat kinerja sistem struktur akan selalu berhubungan dengan biaya perbaikan terhadap kerusakan bangunan tersebut. Dalam desain struktur berbasis kinerja biasanya kinerja didesain sesuai dengan tujuan dan fungsi bangunan dengan pertimbangan faktor ekonomi terhadap biaya perbaikan saat terjadi gempa tanpa mengesampingkan keselamatan terhadap penghuni yang ada dalam bangunan tersebut.

Analisa statik non-linier merupakan prosedur analisa untuk mengetahui perilaku keruntuhan suatu bangunan terhadap gempa, dikenal pula sebagai analisa pushover atau analisa beban dorong statik. Analisa dilakukan dengan memberikan suatu pola beban lateral statik pada struktur, yang kemudian secara bertahap ditingkatkan dengan faktor pengali sampai satu target perpindahan lateral dari suatu titik acuan tercapai. Biasanya titik tersebut adalah titik pada atap, atau lebih tepat lagi adalah pusat massa atap. Analisa pushover menghasilkan kurva pushover, kurva yang menggambarkan hubungan antara gaya geser dasar (V) versus perpindahan titik acuan pada atap (D). Pada proses pushover, struktur didorong sampai mengalami leleh disatu atau lebih lokasi distruktur tersebut. Kurva kapasitas akan memperlihatkan suatu kondisi linier sebelum mencapai kondisi leleh dan selanjutnya berperilaku non-linier. Kurva pushover dipengaruhi oleh pola distribusi gaya lateral yang digunakan sebagai beban dorong.

Tujuan analisa pushover adalah untuk memperkirakan gaya maksimum dan deformasi yang terjadi serta untuk memperoleh informasi bagian mana saja yang kritis. Selanjutnya dapat diidentifikasi bagian-bagian yang memerlukan perhatian khusus untuk pendetailan atau stabilitasnya. Analisa pushover dapat digunakan sebagai 
alat bantu untuk perencanaan tahan gempa, asalkan menyesuaikan dengan keterbatasan yang ada yaitu:

1. Hasil analisa pushover masih berupa suatu pendekatan, karena bagaimanapun perilaku gempa yang sebenarnya adalah bersifat bolak-balik melalui suatu siklus tertentu, sedangkan sifat pembebanan pada analisa pushover adalah statik monotonik.

2. Pemilihan pola beban lateral yang digunakan dalam analisa adalah sangat penting.

3. Untuk membuat model analisa nonlinier akan lebih rumit dibanding model analisa linier. Model tersebut harus memperhitungkan karakteristik inelastik beban deformasi dari elemen-elemen yang penting dan efek PDelta.

Berdasarkan ATC-40 Respon bangunan terhadap gerakan tanah akibat gempa menyebabkan perpindahan lateral dan deformasi pada setiap element struktur. Pada level respon rendah, deformasi element akan dalam rentang elastis (linier) dan tidak aka nada kerusakan yang timbul. Pada level respon tinggi, deformasi elemen akan melebihi kapasitas linier elastis dan bangunan mengalami kerusakan. Faktor-faktor dasar yang mempengaruhi kemampuan sistem penahan gaya laterak untuk melakukan hal tersebut meliputi massa bangunan, kekakuan, dan karakter gerakan tanah [4].

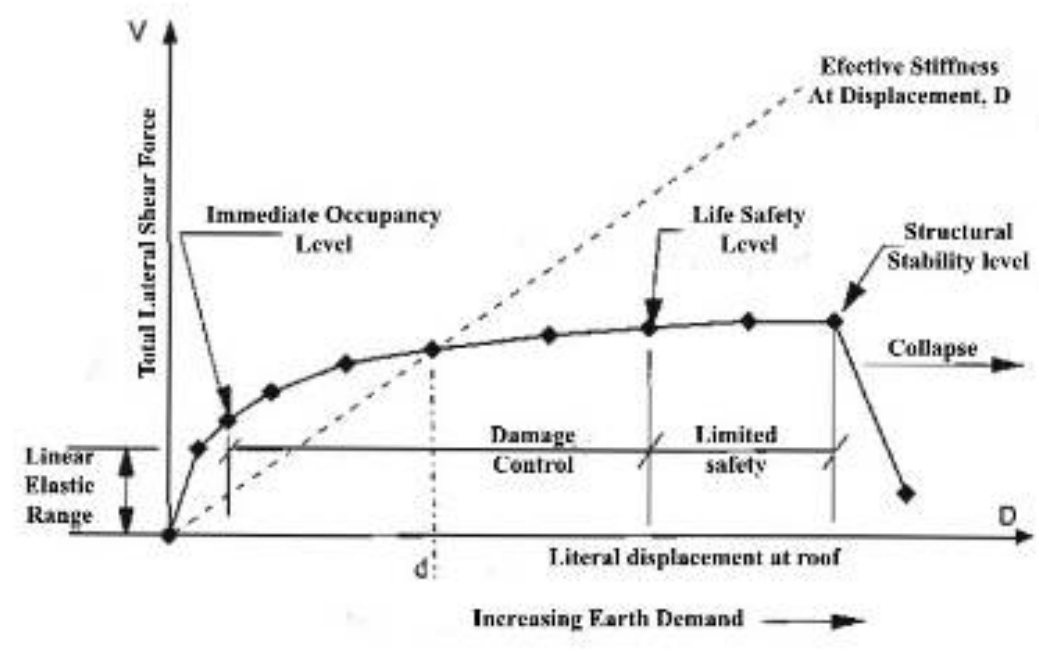

Gambar 1. Tipikal kurva kapasitas pada berbagai tingkat kinerja struktur (ATC-40, 1996) [5]

\section{Hasil}

\subsection{Temperatur Udara}

Kurva kapasitas menunjukkan hubungan antara gaya dan perpindahan yang terjadi hingga struktur runtuh. Perpindahan yang ditinjau adalah perpindahan atap dan

\begin{tabular}{lll}
\multicolumn{3}{c}{ Tabel 1. Displacement dan Base Force (Push X) } \\
\hline Step & Displacement $(\mathrm{m})$ & $\begin{array}{l}\text { Base Force } \\
(\mathrm{kN})\end{array}$ \\
\hline 0 & 0,001666 & 0 \\
1 & $-0,006927$ & 1677,427 \\
2 & $-0,062759$ & 9394,624 \\
3 & $-0,092689$ & 11378,209 \\
4 & $-0,189356$ & 15120,104 \\
5 & $-0,268511$ & 17364,293
\end{tabular}

gaya geser dasar (base shear). Berikut ini nilai dari displacement dan base force push $\mathrm{x}$ dan push $\mathrm{y}$ sebagaimana disajikan pada Tabel 1 dan Tabel 2.

\begin{tabular}{lll}
\multicolumn{3}{l}{ Tabel 2. Displacement dan Base Force $($ Push $\mathrm{Y})$} \\
\hline Step & Displacement $(\mathrm{m})$ & $\begin{array}{l}\text { Base Force } \\
(\mathrm{kN})\end{array}$ \\
\hline 0 & $-0,002668$ & 0 \\
1 & $-0,009519$ & 1214,9 \\
2 & $-0,065532$ & 9387,759 \\
3 & $-0,083435$ & 10759,674 \\
4 & $-0,083445$ & 10735,251 \\
5 & $-0,138191$ & 13184,479 \\
6 & $-0,18693$ & 14489,245 \\
7 & $-0,18993$ & 14540,78 \\
8 & $-0,195931$ & 14671,201 \\
9 & $-0,198937$ & 14705,136 \\
\hline
\end{tabular}




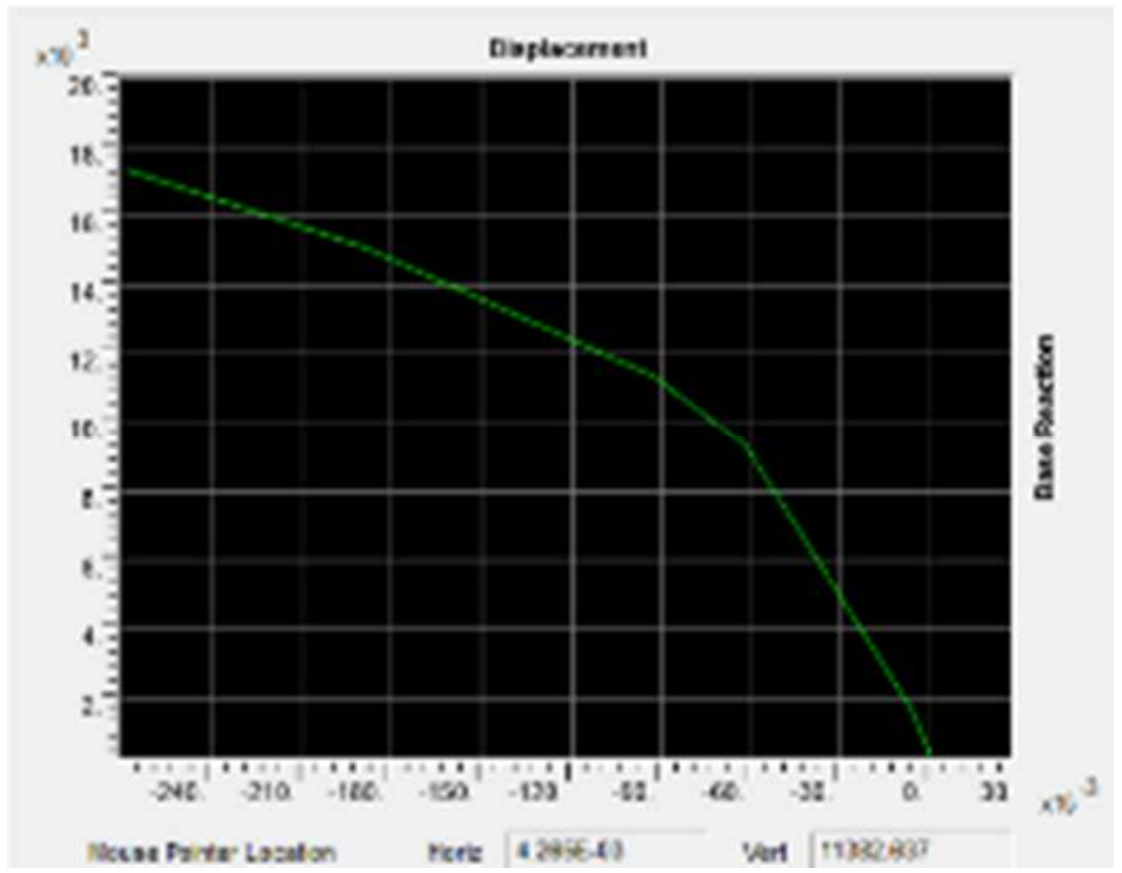

Gambar 2. Kurva kapasitas Push X

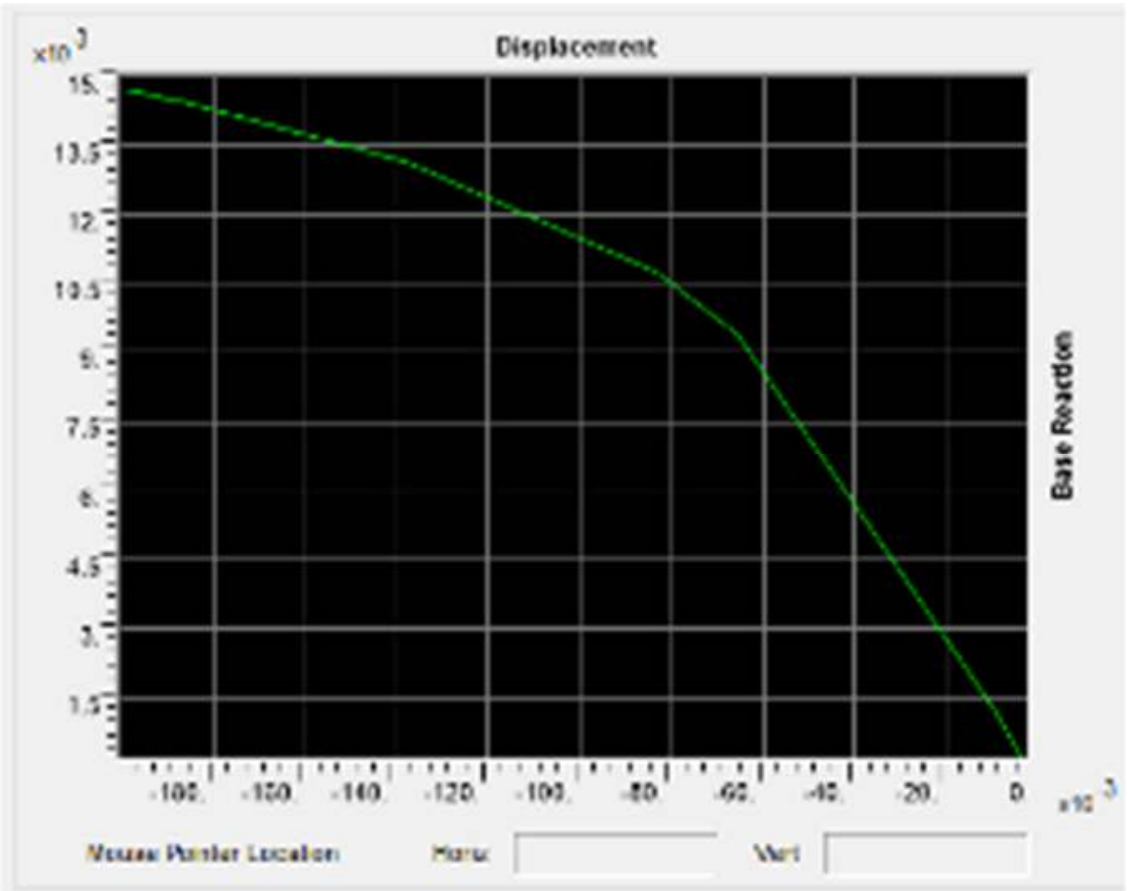

Gambar 3. Kurva kapasitas Push Y

Berdasarkan hasil perhitungan analisis pushover besarnya gaya leteral maksimum untuk push $x$ yang mampu ditahan oleh struktur sebesar 17364,293 kN yang terjadi terjadi pada step 5, dengan displacement $0,2685 \mathrm{~m}$. Gaya lateral yang mampu ditahan untuk push y sebesar $14705,136 \mathrm{kN}$ yang terjadi pada step 9 , dengan displacement $0,1989 \mathrm{~m}$.
Berdasarkan kurva respons spektrum rencana dari peta gempa 2017 untuk wilayah Pemalang dengan kondisi tanah sedang untuk nilai $\mathrm{Ss}=0,6$ dan $\mathrm{S} 1=0,25$ sebagai input analisis pushover dalam format ADRS (acceleration-displacement respons spectrum). Nilai $\mathrm{C}_{\mathrm{a}}$ dan $\mathrm{C}_{\mathrm{v}}$ berdasarkan ATC-40 pasal 4.4.3.1 didapatkan nilai $\mathrm{C}_{\mathrm{a}}=0,3168$ dan $\mathrm{C}_{\mathrm{v}}=0,48$ yang dimasukan di dalam menu Pushover Parameter Set. 
Titik kinerja (performance point) atau target perpindahan gedung merupakan perpotongan antar kurva spektrum kapasitas dan spektrum demand dalam format ADRS, yang menunjukan bagaimana kekuatan struktur memenuhi suatu beban yang diberikan dari Gambar 4 dan Gambar 5 didapatkan nilai target perpindahan dan gaya geser dasar pada titik kontrol tinjauan yang dapat dilihat pada Tabel 3 berikut:

Tabel 3. Level Kinerja Gedung

\begin{tabular}{cccccc}
\hline $\begin{array}{c}\text { Metode } \\
\begin{array}{c}\text { Spektrum } \\
\text { Kapasitas }\end{array}\end{array}$ & $\begin{array}{c}\text { Elevasi } \\
\text { Gedung }(\mathrm{m})\end{array}$ & $\begin{array}{c}\text { Drift Ratio } \\
\delta t\end{array}$ & $\frac{\delta_{t}}{H}$ & $\begin{array}{c}\text { Batasan } \\
\text { Displacement } \\
(\mathrm{m})\end{array}$ & $\begin{array}{c}\text { Level } \\
\text { Kinerja } \\
\text { Gedung }\end{array}$ \\
\hline Arah-X & 24 & 0,104 & 0,00433 & 0,36 & IO \\
Arah-Y & 24 & 0,098 & 0,00408 & & IO \\
\hline
\end{tabular}

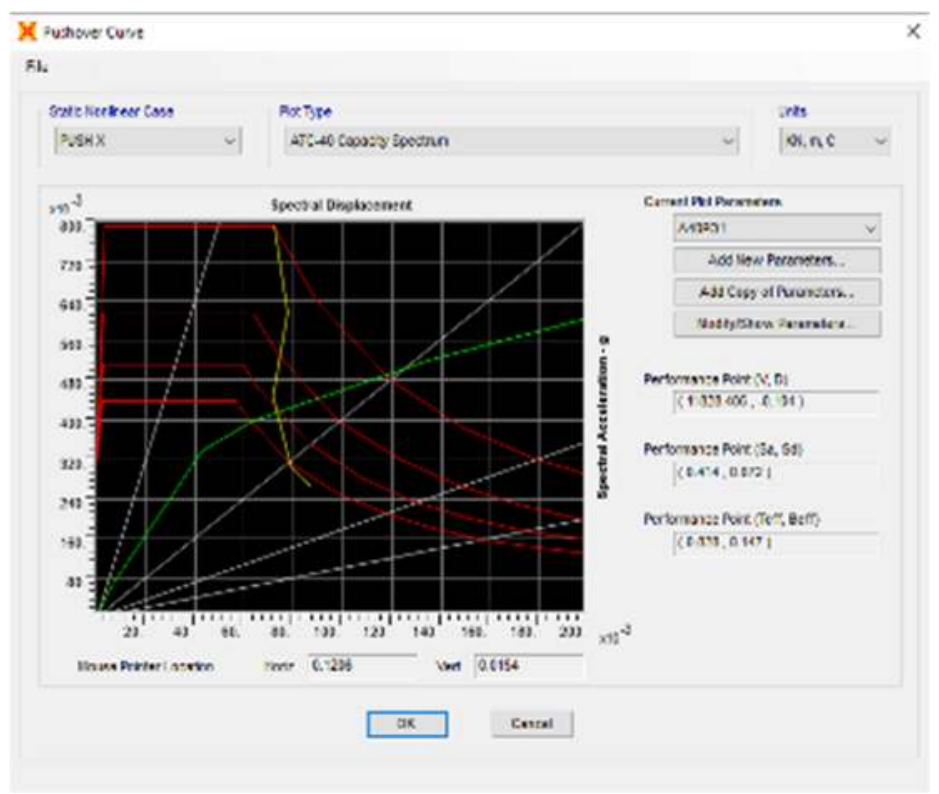

Gambar 4. Grafik ATC-40 (Push X)

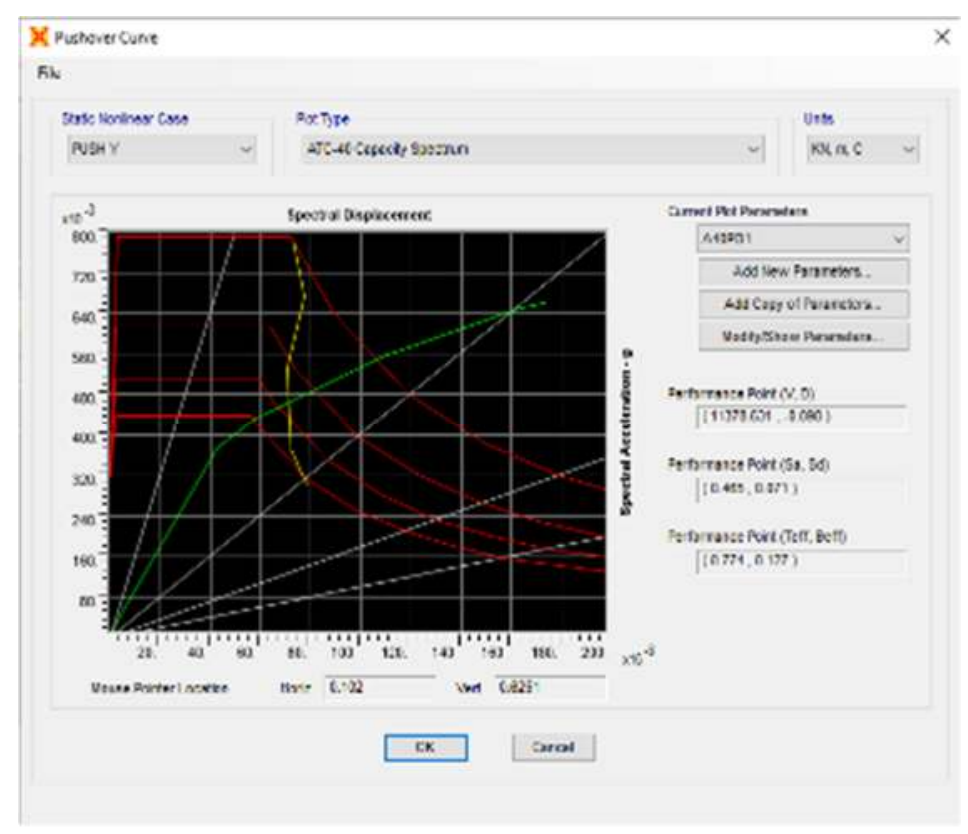

Gambar 5. Grafik ATC-40 (Push Y) 
Berdasarkan hasil perhitungan pada Tabel 3 diperoleh nilai simpangan maksimum (drift ratio) saat performance point dibagi dengan total tinggi bangunan diperoleh rasio arah $\mathrm{x}$ sebesar $0,00433<0,01$ dan rasio arah y sebesar $0,00408<$ 0,01 . Menunjukan bahwa gedung yang ditinjau termasuk dalam level kinerja Immediate occupancy (IO), hal ini berarti bahwa kondisi bangunan pasca terjadi gempa, gedung tidak mengalami kerusakan struktur yang berarti dan dapat segera difungsikan kembali.

Metode FEMA 440 [6] secara garis besar hasil akhir hitungan ini sama dengan FEMA 356 [7], yaitu dengan hasil akhir menentukan nilai target perpindahan untuk menentukan level kinerja. Kurva kapasitas metode FEMA 440 dapat dilihat pada Gambar 6 dan Gambar 7 berikut:

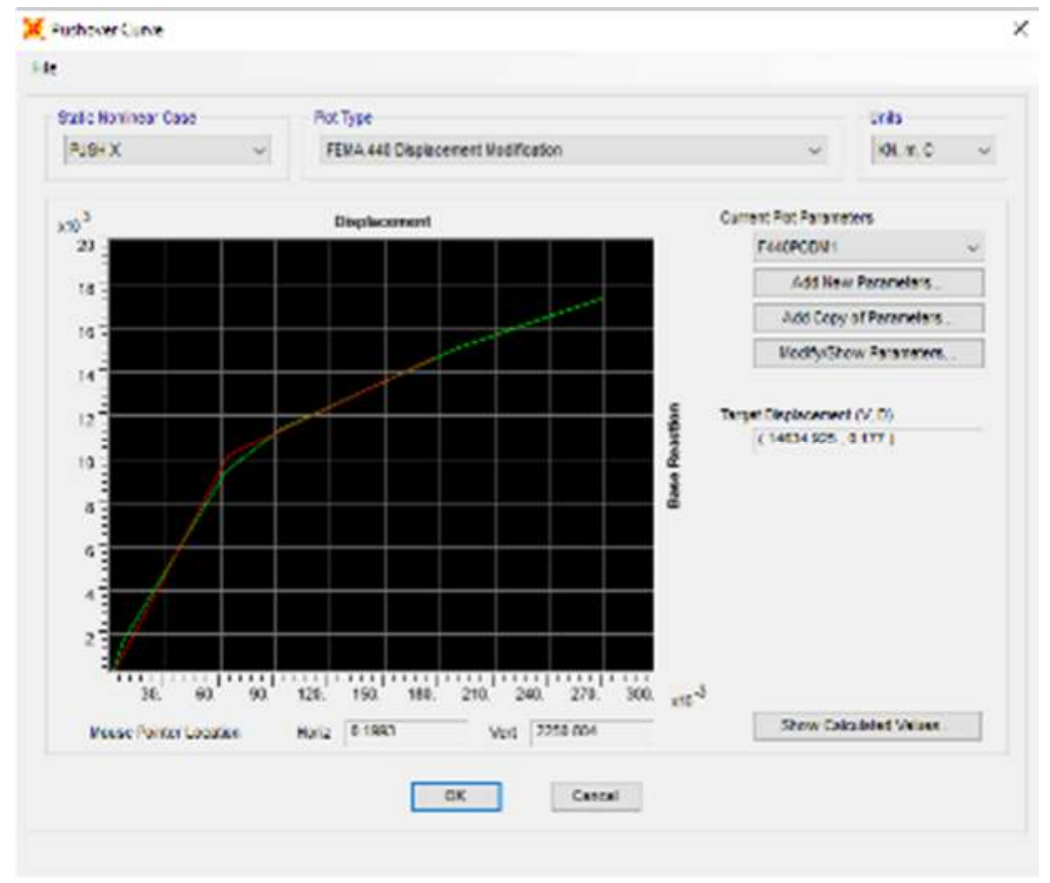

Gambar 6. Grafik FEMA 440 (Push X)

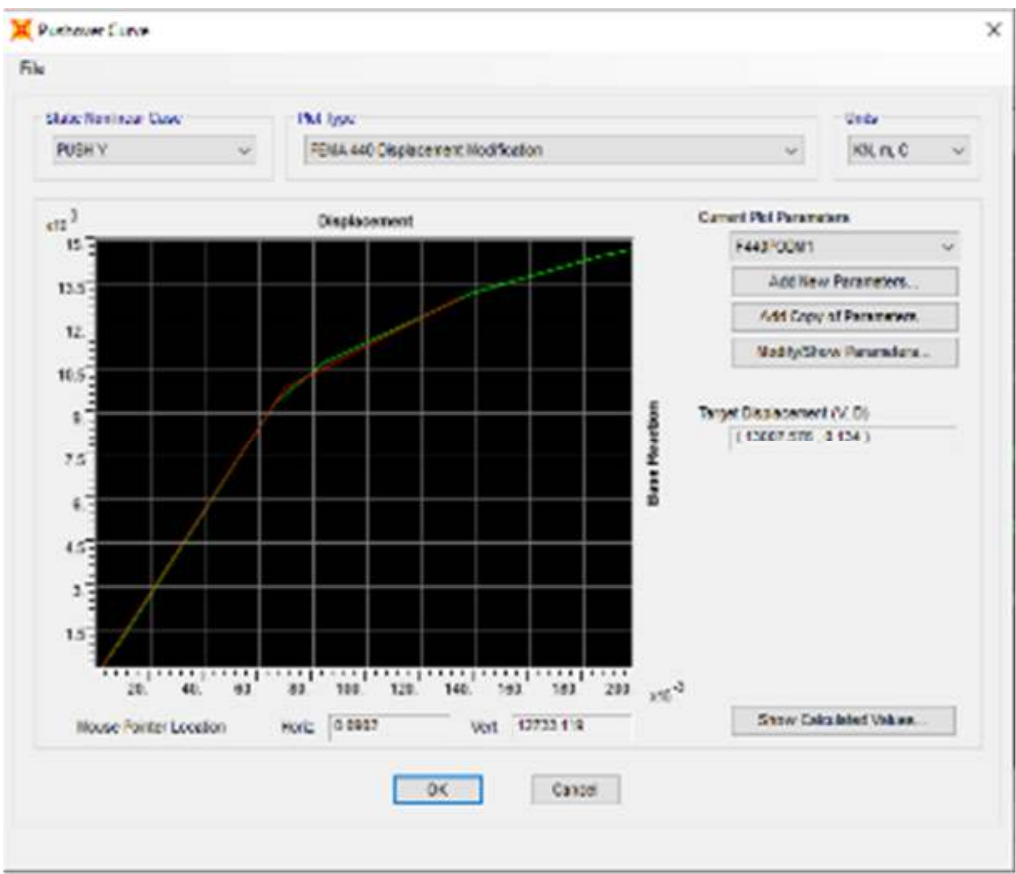

Gambar 7. Grafik FEMA 440 (Push Y) 
Tabel 4. Parameter Target Perpindahan FEMA 440 (Push X)

\begin{tabular}{ccc} 
C0 1 & 1,41824 \\
$\mathrm{C} 1$ & 1,05512 \\
$\mathrm{C} 2$ & 1 & 1 \\
$\mathrm{C} 3$ & 0,85472 \\
$\mathrm{Sa}$ & 0,74877 \\
$\mathrm{Te}$ & 0,60453 \\
$\mathrm{Ti}$ & 10134,169 \\
$7 \mathrm{Vy}$ & 0,064205 \\
$\mathrm{Dy}$ & 242144,92 \\
$\mathrm{Ki}$ & 157840,04 \\
$\mathrm{Ke}$ & 0,2532 \\
Alpha & 2,85436 \\
$\mathrm{R}$ & 33843,176 \\
Weight & 1 \\
Cm & 1 \\
\hline
\end{tabular}

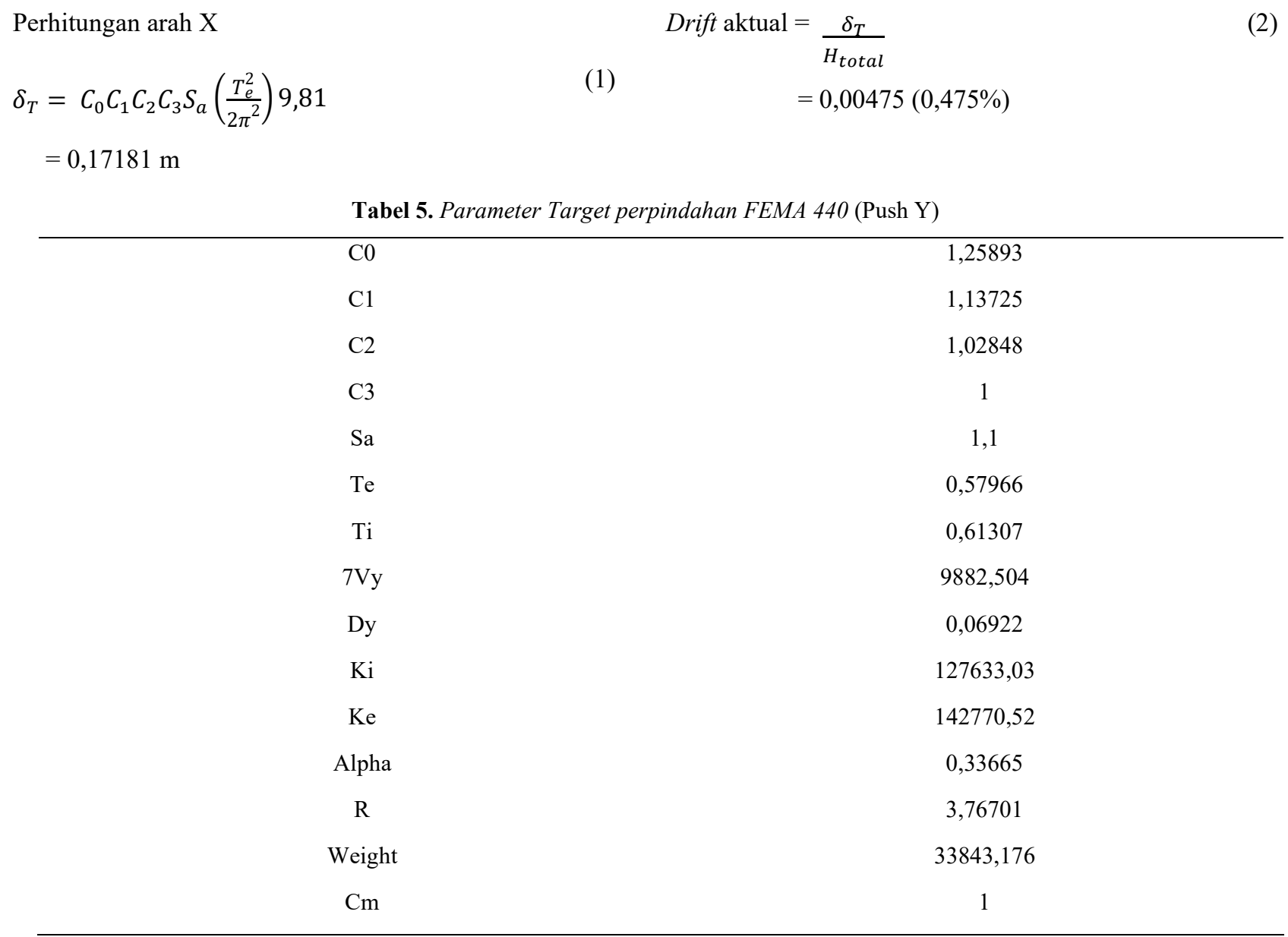

Perhitungan arah Y

$$
\delta_{\mathrm{T}}=\mathrm{C}_{0} \mathrm{C}_{1} \mathrm{C}_{2} \mathrm{C}_{3} \mathrm{~S}_{\mathrm{a}}\left(\frac{\mathrm{T}_{\mathrm{e}}^{2}}{2 \pi^{2}}\right) 9,81
$$




$$
=0,13524 \mathrm{~m}
$$

Drift aktual $=\frac{\delta_{\mathrm{T}}}{\mathrm{H}_{\text {total }}}$

$$
=0,00275(0,275 \%)
$$

Berdasarkan perbandingan nilai persentase Drift Aktual dengan batasan simpangan level kinerja struktur pada FEMA 356, didapatkan bahwa struktur para arah X dan arah Y berada pada level kinerja Immediate Occupancy (IO).

Berdasarkan analisis statik non-linear yang dilakukan hingga mendapatkan perilaku inelastic pasca keruntuhan bangunan, maka diperoleh gambar pendistribusian sendi plastis perlangkah pada portal yang juga menjadi titik kontrol case PUSH. Mekanisme distribusi sendi plastis dapat dilihat pada Gambar 8 sampai dengan Gambar 23.

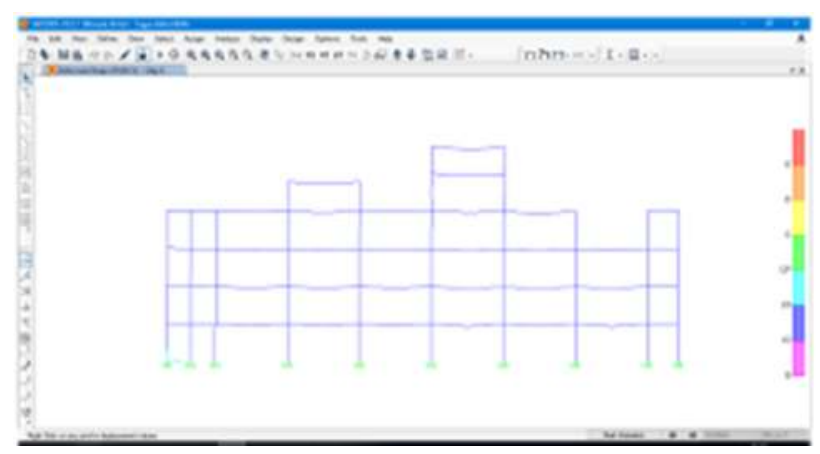

Gambar 8. Mekanisme sendi plastis step 0 (Push X)

Pada step ke 0 elemen yang berada pada kondisi B-IO adalah 6 sisanya masih berada pada kondisi A-B.

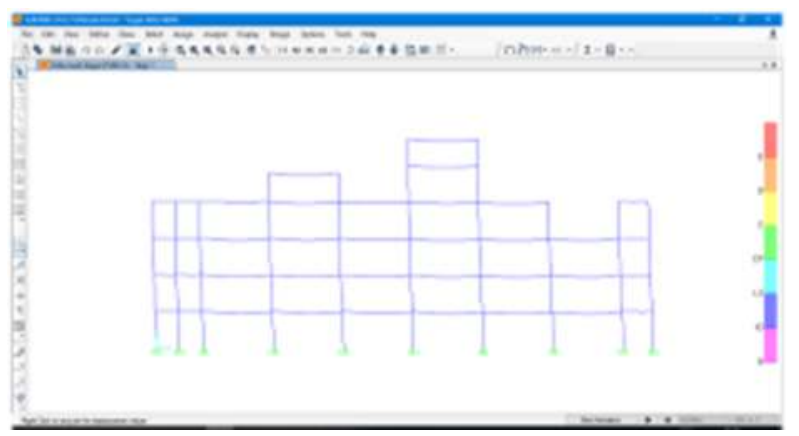

Gambar 9. Mekanisme Sendi Plastis Step 1 (Push X)

Pada step ke 1 elemen yang berada pada kondisi B-IO adalah 7 sisanya masih berada pada kondisi A-B.

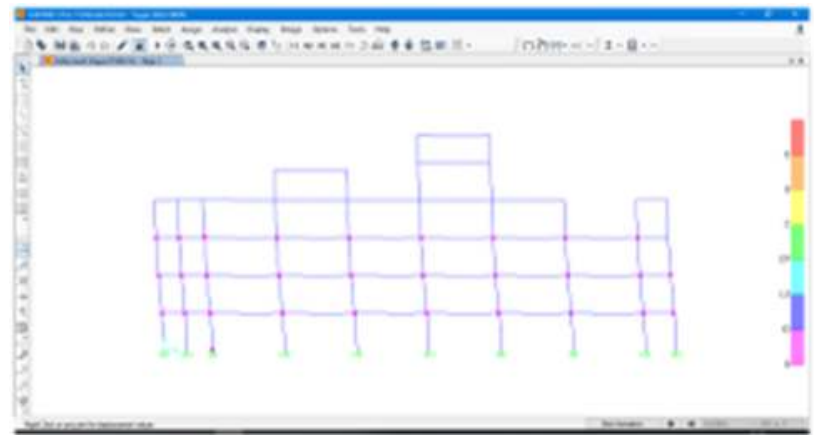

Gambar 10. Mekanisme sendi plastis step 2 (Push X)

Pada step ke 2 elemen yang berada pada kondisi B-IO adalah 264 sisanya masih berada pada kondisi A-B.

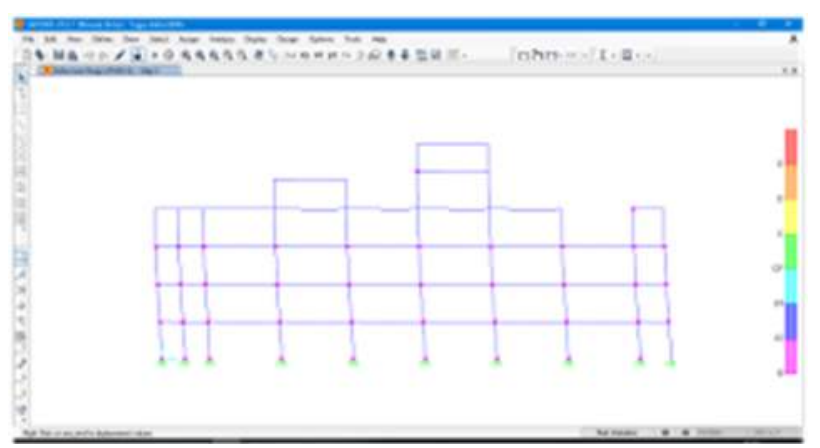

Gambar 11. Mekanisme sendi plastis step 3 (Push X)

Pada step ke 3 elemen yang berada pada kondisi B-IO adalah 353 sisanya masih berada pada kondisi A-B.

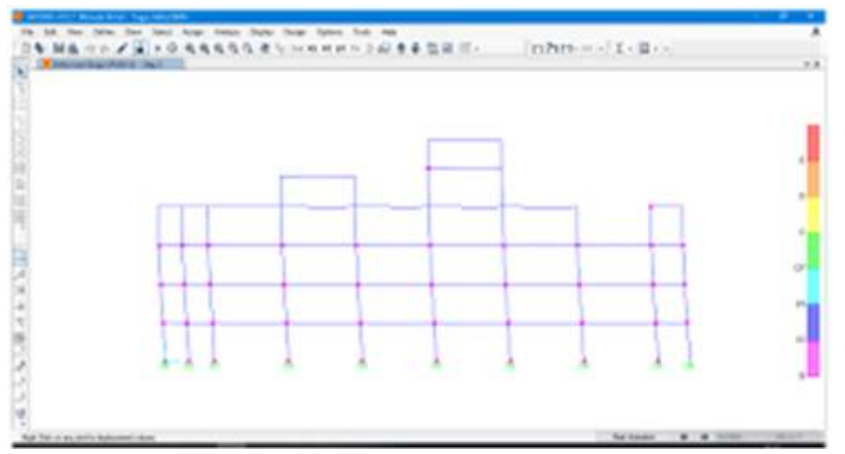

Gambar 11. Mekanisme sendi plastis step 3 (Push X)

Pada step ke 1 elemen yang berada pada kondisi B-IO adalah 7 sisanya masih berada pada kondisi A-B. 


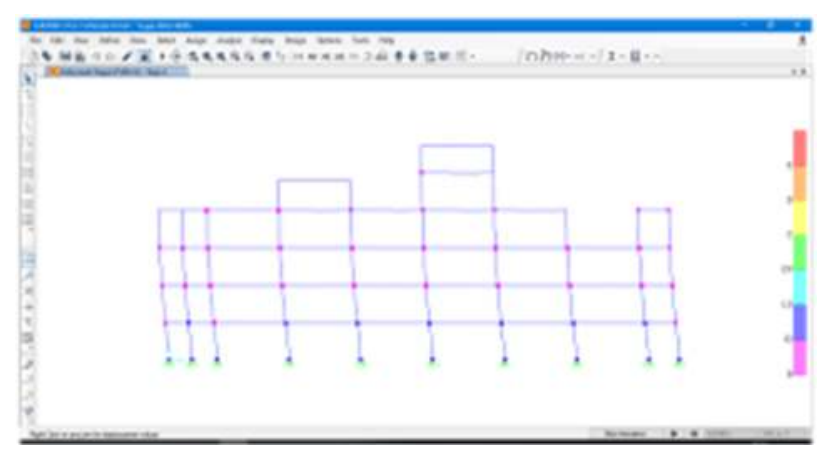

Gambar 12. Mekanisme sendi plastis step 4 (Push X)

Pada step ke 4 elemen sudah berada di kondisi IO-LS sebanyak 105 dan pada kondisi B-IO adalah 422 sisanya masih berada pada kondisi A-B.

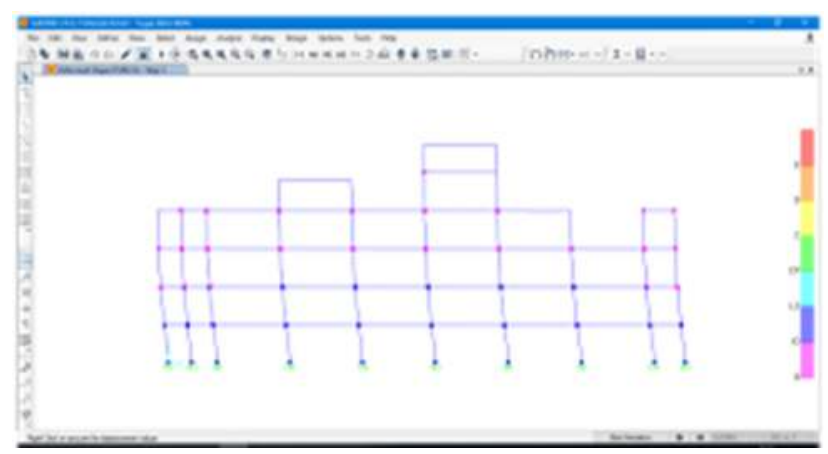

Gambar 13. Mekanisme sendi plastis step 5 (Push X)

Pada step ke 5 elemen yang berada pada kondisi IO-LS adalah 227 dan pada kondisi B-IO adalah 426 sisanya masih berada pada kondisi A-B

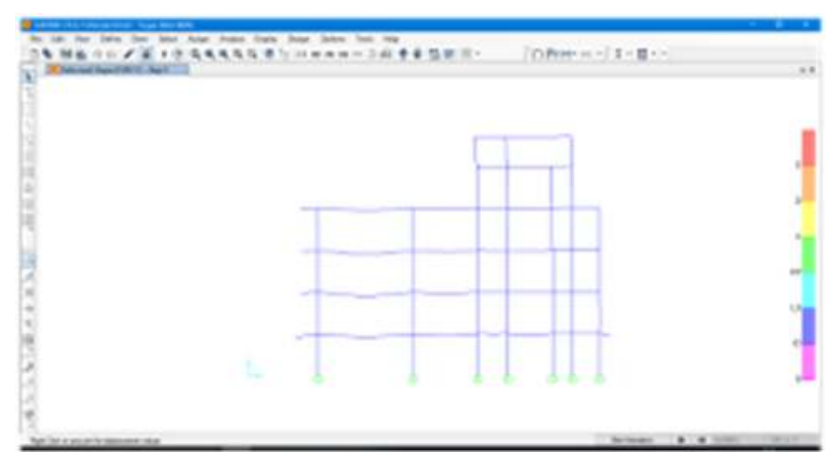

Gambar 14. Mekanisme sendi plastis step 0 (Push Y)

Pada step ke 0 elemen yang berada pada kondisi B-IO adalah 6 sisanya masih berada pada kondisi A-B.

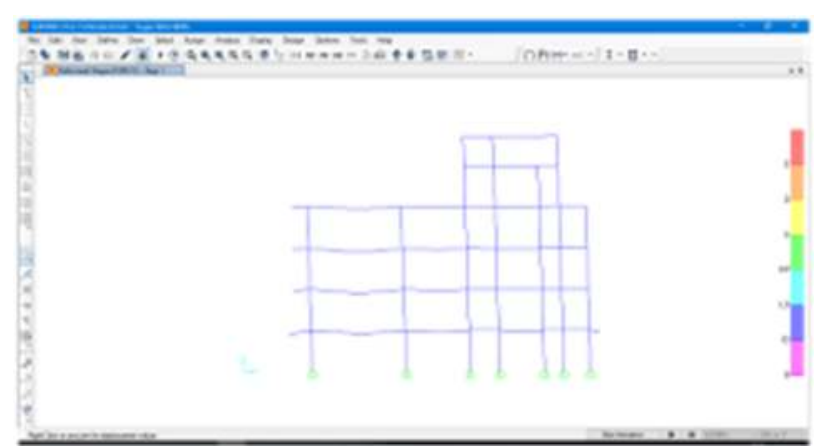

Gambar 15. Mekanisme sendi plastis step 1 (Push Y)

Pada langkah ke 1 elemen yang berada pada kondisi B-IO adalah 7 sisanya masih berada pada kondisi A-B.

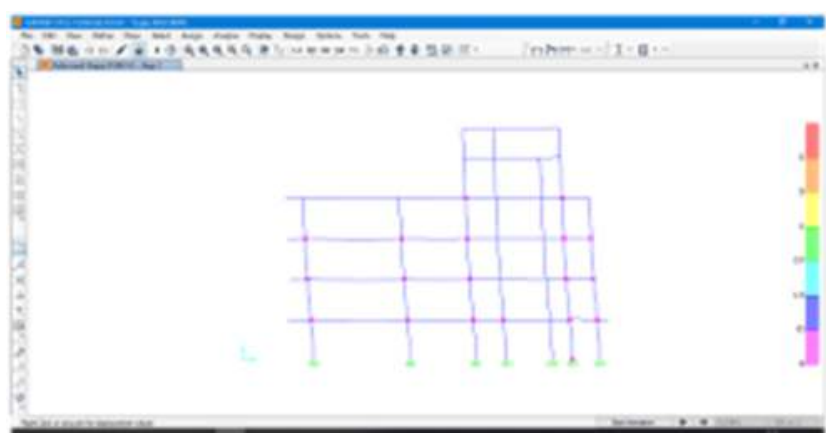

Gambar 16. Mekanisme Sendi plastis step 2 (Push Y)

Pada step ke 2 elemen yang berada pada kondisi B-IO adalah 171 sisanya masih berada pada kondisi A-B.

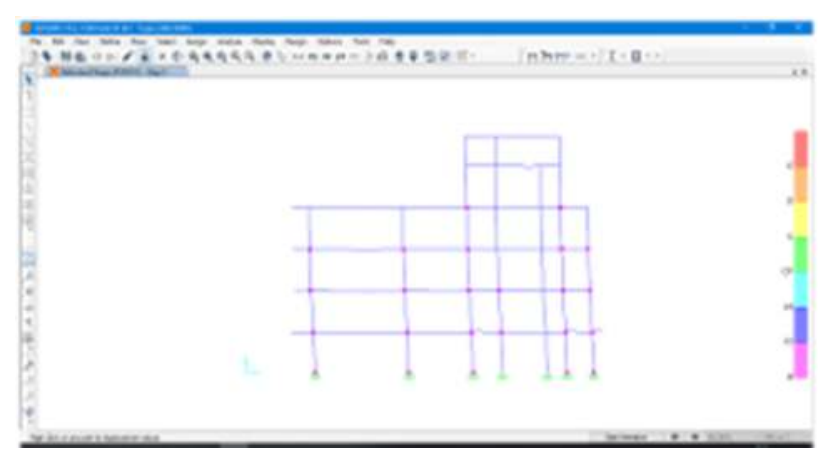

Gambar 17. Mekanisme sendi plastis step 3 (Push Y)

Pada step ke 3 elemen yang berada pada kondisi B-IO adalah 262 sisanya masih berada pada kondisi A-B. 


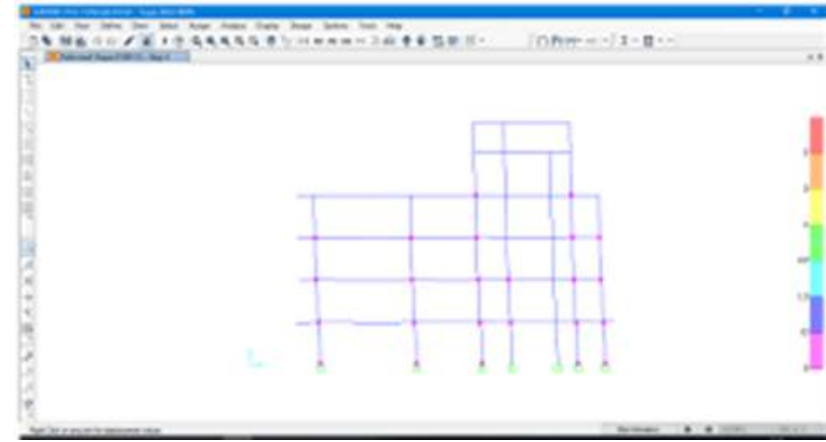

Gambar 18. Mekanisme sendi plastis step 4 (Push Y)

Pada step ke 4 elemen yang berada pada kondisi B-IO adalah 262 sisanya masih berada pada kondisi A-B.

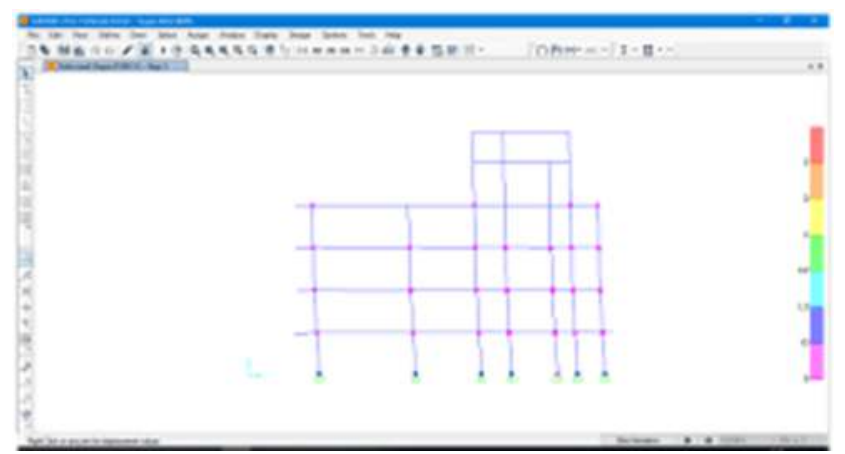

Gambar 19. Mekanisme sendi plastis step 5

(Push Y)

Pada step ke 5 elemen yang berada pada kondisi IO-LS adalah 50 dan pada kondisi B-IO adalah 399 sisanya masih berada pada kondisi A-B.

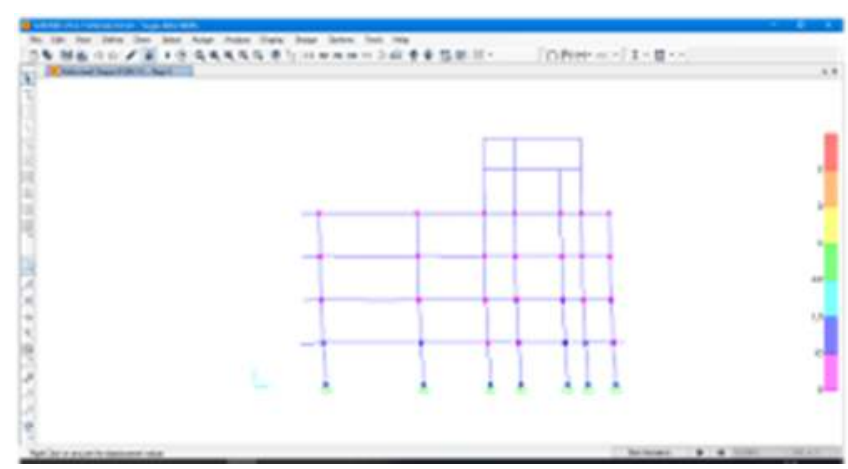

Gambar 20. Mekanisme sendi plastis step 6 (Push Y)

Pada step ke 6 elemen yang berada pada kondisi IO-LS adalah 112 dan pada kondisi B-IO adalah 434 sisanya masih berada pada kondisi A-B

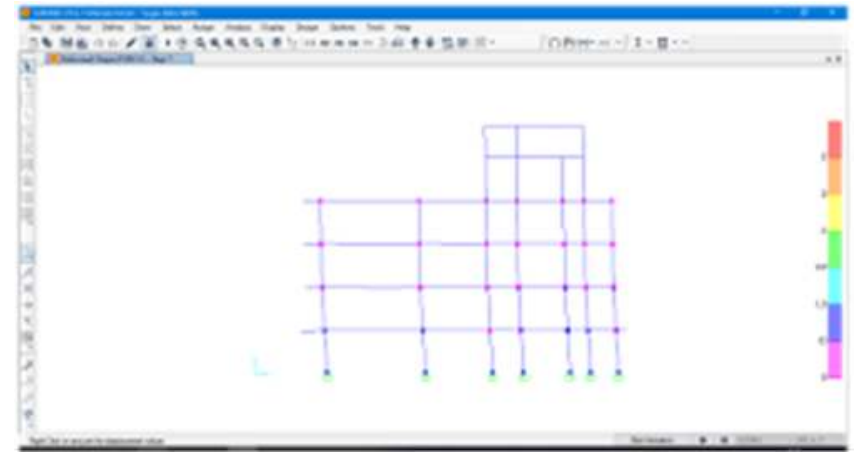

Gambar 21. Mekanisme sendi plastis step 7 (Push Y)

Pada step ke 7 sudah ada elemen yang berada pada kondisi C-D adalah 1, pada kondisi IO-LS adalah 117 dan pada kondisi B-IO adalah 436 sisanya masih berada pada kondisi A-B

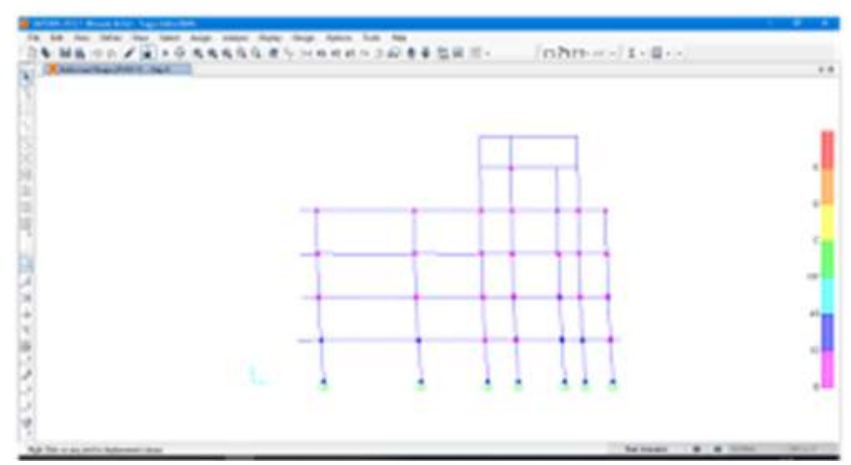

Gambar 22. Mekanisme sendi plastis step 8 (Push Y)

Pada step ke 8 sudah ada elemen yang berada pada kondisi C-D adalah 1, pada kondisi IO-LS adalah 117 dan pada kondisi B-IO adalah 436 sisanya masih berada pada kondisi A-B

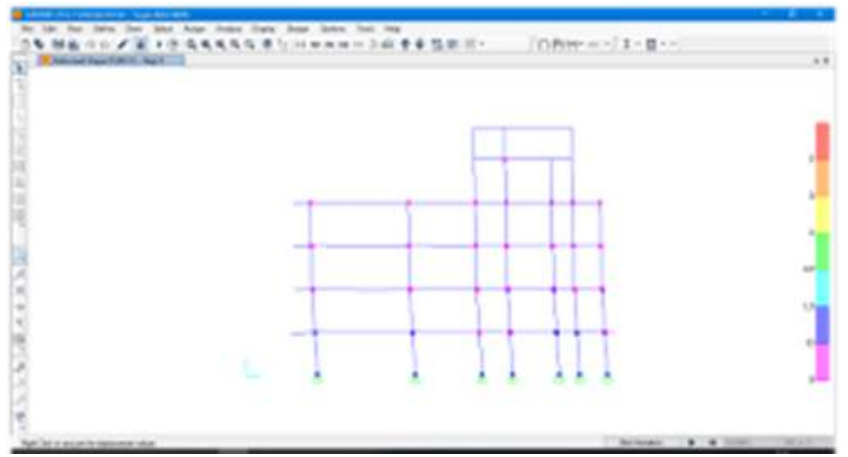

Gambar 23. Mekanisme sendi plastis step 9 (Push Y)

Pada step ke 9 sudah ada elemen yang berada pada kondisi C-D adalah 1, pada kondisi IO-LS adalah 119 dan pada kondisi B-IO adalah 436 sisanya masih berada pada kondisi A-B. 
Tabel 6. Distribusi Sendi Plastis (Push X)

\begin{tabular}{cccccccccc}
\hline Step & A - B & B - IO & IO - LS & LS - CP & CP - C & C -D & D - E & >E & Total \\
\hline 0 & 1776 & 6 & 0 & 0 & 0 & 0 & 0 & 0 & 1782 \\
1 & 1775 & 7 & 0 & 0 & 0 & 0 & 0 & 0 & 1782 \\
2 & 1518 & 264 & 0 & 0 & 0 & 0 & 0 & 0 & 1782 \\
3 & 1429 & 353 & 0 & 0 & 0 & 0 & 0 & 0 & 1782 \\
4 & 1255 & 422 & 105 & 0 & 0 & 0 & 0 & 0 & 1782 \\
5 & 1129 & 426 & 227 & 0 & 0 & 0 & 0 & 0 & 1782 \\
\hline
\end{tabular}

Tabel 7. Distribusi Sendi Plastis (Push X)

\begin{tabular}{cccccccccc}
\hline Step & A - B & B - IO & IO - LS & LS - CP & CP - C & C -D & D - E & $>$ E & Total \\
\hline 0 & 1776 & 6 & 0 & 0 & 0 & 0 & 0 & 0 & 1782 \\
1 & 1775 & 7 & 0 & 0 & 0 & 0 & 0 & 0 & 1782 \\
2 & 1611 & 171 & 0 & 0 & 0 & 0 & 0 & 0 & 1782 \\
3 & 1520 & 262 & 0 & 0 & 0 & 0 & 0 & 0 & 1782 \\
4 & 1520 & 262 & 0 & 0 & 0 & 0 & 0 & 0 & 1782 \\
5 & 1333 & 399 & 50 & 0 & 0 & 0 & 0 & 0 & 1782 \\
6 & 1236 & 434 & 112 & 0 & 0 & 0 & 0 & 0 & 1782 \\
7 & 1235 & 432 & 114 & 0 & 0 & 1 & 0 & 0 & 1782 \\
8 & 1228 & 436 & 117 & 0 & 0 & 1 & 0 & 0 & 1782 \\
9 & 1226 & 436 & 119 & 0 & 0 & 1 & 0 & 0 & 1782 \\
\hline
\end{tabular}

\section{Simpulan}

Berdasarkan pembahasan dan hasil berdasarkan hasil analisa data yang dilakukan, diperoleh kesimpulan: (1) Sebagian besar sendi plastis balok dan kolom masih dalam level Immediate Occupancy (IO) sehingga dapat dikatakan kinerja komponen struktur masih dalam keadaan aman pada saat target perpindahan tercapai.; (2) Hasil perhitungan dengan bantuan software SAP2000 v.19 diperoleh gaya geser dasar (base shear) arah $\mathrm{x}=$ $17364,294 \mathrm{kN}$ dan arah y $=14705,136 \mathrm{kN}$; (3) Hasil perhitungan dengan bantuan software SAP2000 v.19; (4) Evaluasi tingkat kinerja struktur menggunakan ATC-40, menunjukan nilai maximum total drift arah x 0,00433 dan maximum total drift arah y 0,00408 dan berada pada level kinerja Immediate Occupancy (IO); dan (5) Evaluasi tingkat kinerja struktur menggunakan FEMA 440, menunjukkan nilai target perpindahan sebesar $=0,17819$ $\mathrm{m}$ pada arah $\mathrm{x}$, dan nilai target perpindahan sebesar $=$
0,13524 m pada arah y. Level kinerja berada pada level Immediate Occupancy (IO).

\section{Daftar Rujukan}

[1] Badan Standarisasi Nasional, Standart Perancangan Gempa Untuk Struktur Bangunan Gedung Dan Struktur Lain (SNI 03-1726:2012). Jakarta: Badan Standarisasi Nasional, 2012.

[2] Bandan Standarisasi Nasional, Beban Minimum Untuk Perancangan Bangunan Gedung Dan Struktur Lain (SNI 03-1727:2013). Jakarta: Bandan Standarisasi Nasional, 2012.

[3] A. A. Masagala and F. Ma'arif, "Perencanaan Struktur Beton Bertulang Tahan Gempa Berlantai 4 (Studi Kasus Gedung Baru Kampus I Universitas Teknologi Yogyakarta)," Semesta Teknika, vol. 19, no. 1, pp. 8089, Dec. 2016, doi: 10.18196/ST.V19I1.1829.

[4] Applied Technology Council, "ATC-40 Seismic Evaluation and Retrofit of Concrete Buildings Volume 1," California, 1996. 
[5] Tavio and U. Wijaya, Desain Rekayasa Gempa Berbasis Kinerja (Performance Based Design) Dilengkapi Contoh Dan Aplikasi Program Etabs. Jakarta: Andi Offset, 2018.

[6] Federal Emergency Management Agency 440, "Improvement of Nonlinear Static Seismic Analysis Procedures," Washington, D.C., 2004.

[7] Federal Emergency Management Agency 356, "Prestandard and Commentary for the Seismic Rehabilitation of Buildings," Federal Emergency Management Agency, Washington, D.C., 2000.
[8] N. A. Munawaroh, "Evaluasi Kinerja Bangunan Gedung Dengan Pushover Analisis Menggunakan program SAP2000 (Studi Kasus: Awana Condotel Yogyakarta)," Universitas Teknologi Yogyakarta, 2018.

[9] Y. A. Pranata, "Evaluasi Kinerja gedung Beton Bertulang Tahan Gempa dengan Pushover Analysis," Universitas Kristen Maranatha Bandung, 2006. 